\title{
Financial Behaviors of Female Teachers in Malaysia
}

\author{
Zaimah R. ${ }^{1}$, Sarmila M. S. ${ }^{1}$, N. Lyndon ${ }^{1}$, Azima A. M. ${ }^{1}$, S. Selvadurai ${ }^{1}$, Suhana $\operatorname{Saad}^{1}$ \& A. C. Er ${ }^{1}$ \\ ${ }^{1}$ School of Social, Development \& Environmental Studies, Faculty of Social Sciences \& Humanities, Universiti \\ Kebangsaan Malaysia, Bangi, Selangor, Malaysia \\ Correspondence: Zaimah R., School of Social, Development \& Environmental Studies, Faculty of Social Sciences \\ \& Humanities, Universiti Kebangsaan Malaysia, Bangi, Selangor, Malaysia. Tel: 60-3-8921-3123. E-mail: \\ zaimahr@ukm.my
}

\author{
Received: February 12, 2013 Accepted: March 29, 2013 Online Published: April 25, 2013 \\ doi:10.5539/ass.v9n8p34 \\ URL: http://dx.doi.org/10.5539/ass.v9n8p34
}

\begin{abstract}
This paper aims to identify the pattern of financial behavior among female teachers in Bandar Baru Bangi, Selangor. A total of 325 female teachers was involved in the study. Questionnaires were used in the survey to collect data. Data on questions relating to socioeconomic background, financial knowledge and financial behavior were gathered. The financial behavior pattern was formulated using the 5-Likert scale and financial knowledge with the choice of either 'right' or 'wrong' answer. The analysis showed four dimensions that were interrelated on the assessment measurement of financial behavior: i) planning, ii) cash flow management, iii) saving and iv) usage of credit card. Descriptive analysis includes t-test and ANOVA were used to analyze the differences between the mean score of financial behavior across the factors such as age, level of education, monthly income and financial knowledge level. The findings showed the respondents had a substantial mean score in the four dimensions of financial behavior described above. The highest mean score was on the dimension of cash flow management which involve activities of paying bills and other expenses by installments. The findings also showed respondents aged more than 45 years old had good financial behavior in term of saving. In another word, as they grew older they cultivate better saving habit. The findings also showed that the respondents with the good financial behavior were among those who were good in saving their income. Further study is suggested to identify factors that influence the financial behavior among teachers. The financial behavior can describe the financial well-being of an individual or group which has an impact on the individual productivity level.
\end{abstract}

Keywords: financial behavior, financial knowledge, financial well-being, female teacher

\section{Introduction}

Efforts in improving the financial well-being of an individual, family and society should give greater emphasis to aspects of financial behavior. Financial behavior refers to one's practice of using a systematic financial management system, for example a consistent savings plan through well thought and written plan with specific aims (Titus et al., 1989). Good financial behavior is described by having effective behavior such as preparing financial record, documentation on the cash flow, planning expenses, paying utility bills, controlling the usage of credit card as well as a savings plan (Gorham et al., 1998). Prior research did describe how financial well-being of an individual are influenced by his or her financial behavior (Godwin \& Carrol, 1986; Scannel, 1990; Porter \& Garman, 1993; Godwin, 1994; DeVaney, Gorham \& Benchman et al., 1996; Parrotta \& Johnson, 1998; Joo \& Garman, 1998; Hira \& Mugenda, 1999; Kim et al., 2003; Joo \& Grable, 2004; Kim \& Garman, 2004; Ramli et al. 2010; Ramli, 2011).

The need to investigate financial behavior among teachers is important since teachers are among role model figures who can influence the youngs generation's financial knowledge and skills in personal financial management. In Malaysia, total number of female teachers exceeds the total number of male teachers. Statistic from the Ministry of Education (MOE) in 2012 showed that the total number of female teachers was 285,299 approximately 70 per cent of the total number of all teachers in Malaysia. As such it is important to explore the financial behavior among the female teachers. The aims of this paper are to examine the financial behavior patterns and dimensions among the female teachers, and to identify the difference between of their financial behavior with several factors chosen such as age, education level, monthly income and level of their financial knowledge. 


\section{Literature Review}

The literature on financial behavior shows as having significant relation to the level of education (Hogarth et al., 2002, 2003; Hilgerth \& Hogarth, 2003). Based on the indexes of financial practices, four variables are identified; i) cash flow management, ii) credit management, iii) saving and iv) investment practices, it showed that those who have high scores in financial knowledge also have good practices in financial management (Hilgert \& Hogarth, 2003). It also showed that financial education improves financial knowledge and provide a positive impact on financial behavior.

Several researchers have shown financial behavior as positively correlated with financial well-being (Godwin \& Carrol, 1986; Scannel, 1990; Porter \& Garman, 1993; Godwin, 1994; DeVaney, Gorham, Benchman et al., 1996; Parrotta \& Johnson, 1998; Joo \& Garman, 1998; Hira \& Mugenda, 1999; Kim et al., 2003; Joo \& Grable, 2004; Kim \& Garman, 2004). The similar correlation relationship is observed between financial behavior's varied with the level of satisfaction in life (Xiao \& Shim, 2009). According to Joo \& Grable (2004), financial well-being is closely related with financial behavior, level of financial stress, income, financial knowledge, liquidation of cash, financial tolerance and education.

A good financial behavior decreases the chances of financial distress (Godwin, 1994; Sorhaindo \& Garman, 2002; Kim \& Garman, 2003; Xiao et al., 2004; Baek \& DeVaney, 2004; Husniyah et al., 2005; Husniyah \& Fazilah, 2009). Positive financial behavior such as small personal loan, compliance with budget, decreasing life expenditures, financial planning, investment in pension fund and improving financial saving capable of reducing the financial stress and directly affecting the financial well-being (Sorhaindo \& Garman, 2002). The same situation applies to households that practices paying utility bills on time (Baek \& DeVaney, 2004; Nurul et al., 2005). An individual who spend less than what he or she earns will have better financial well-being (Godwin, 1994; Baek \& DeVaney, 2004).

In addition, socioeconomic factors such as age, marital status, employment status, income, education and positive perception of personal financial competency are significantly correlated with various forms of financial practices (Gorham et al., 1998; Hira \& Mugenda, 2000; Grable \& Joo, 2001; Kim \& Garman, 2003; Husniyah et al., 2005; Husniyah \& Fazilah, 2009). By and large, financial behavior is correlated with financial knowledge and positively correlated with financial well-being. In other words, positive financial behavior will improve the level of financial well-being and vice versa. Finally, financial behavior is also being influenced by socioeconomic factors such as gender, age, education, income and financial knowledge.

\section{Methods}

The study was carried out in Bandar Baru Bangi, Selangor, Malaysia. The sample in the study involves teachers from eight schools in Bandar Baru Bangi. The teachers were chosen as samples because they were the most influential figure in educating the future generation. Data were gathered using a questionnaire distributed to the respondents through the school administrators. The questionnaire consisted of information on socioeconomic background, financial knowledge and financial behavior of the respondents. A total of 395 questionnaires was returned and only 362 were completed. Among the 362 responses, 325 were from female teachers comprised of 90 per cent of the total responses.

In the questionnaire, 12 items used 5-Likert scale question as followed: i) never, ii) seldom, iii) sometimes, iv) often and v) always. The mean score was calculated based on the 5 Likert scale where the higher the score the higher level of financial behavior shown. High level of financial knowledge was measured by the number of answers 'correct' from 15 questions. Levels of financial knowledge were classified into three levels: i) low (score of 1-5), ii) moderate (score of 6-10), and iii) high (score of 10-5). Reliability test of Cronbach Alpha showed 0.720 and 0.450 for financial behavior and financial knowledge respectively.

Factor analysis was carried out to identify elements in various dimensions of financial behavior measurement. Descriptive analysis was also carried out to identify the frequency, percentage, mean and standard deviation used in formulating the findings and discussion. In addition, t-test and ANOVA were used to analyze the differences in financial behavior scores based on variables such as age, education levels, monthly income and financial knowledge.

\section{Findings and Discussion}

\subsection{Respondents Background}

Table 1 showed the information on the respondents' background. The mean age score was less than 40 years old. The age distribution of respondents comprised primarily of the 35 to 45 years old cohorts (44.3\%). More than 90 per cent of the respondents were married. The majority $(84.9 \%)$ of the respondents were graduates. The mean 
length of teaching experiences was 15 years and most of them $(41.2 \%)$ had been teaching from 10 to 11 years old. The percentage of teachers with less than 10 years of experiences was 31.7 per cent which is considered to be relatively high. Similarly, the percentage of respondents who received a monthly income less than RM3500 was 42 per cent. Meanwhile there were nearly one-third (30\%) of the respondents who received monthly income higher than RM4500. Examining at the financial knowledge, the majority of the respondents falls in the moderate range $(70 \%)$ who answered 'correct' on 6 to 10 questions relating to given.

Table 1. Respondents background

\begin{tabular}{|c|c|c|}
\hline Items & Frequency & Percent \\
\hline \multicolumn{3}{|l|}{ Age } \\
\hline$<35$ years old & 86 & 26.5 \\
\hline $35-45$ years old & 144 & 44.3 \\
\hline$>45$ years old & 95 & 29.2 \\
\hline \multicolumn{3}{|l|}{ Marital Status: } \\
\hline Single & 18 & 5.5 \\
\hline Married & 298 & 91.7 \\
\hline Single Parent & 9 & 2.8 \\
\hline \multicolumn{3}{|l|}{ Level of Education: } \\
\hline Non-graduate & 49 & 15.1 \\
\hline Graduate & 276 & 84.9 \\
\hline \multicolumn{3}{|l|}{ Years of Service: } \\
\hline$<10$ years & 103 & 31.7 \\
\hline $11-20$ years & 134 & 41.2 \\
\hline$>20$ years & 88 & 27.1 \\
\hline \multicolumn{3}{|l|}{ Monthly Income: } \\
\hline$<\mathrm{RM} 3500$ & 136 & 41.8 \\
\hline RM3500-RM4500 & 91 & 28.0 \\
\hline$>$ RM4500 & 98 & 30.2 \\
\hline \multicolumn{3}{|l|}{ Financial Education: } \\
\hline Low Level & 9 & 2.8 \\
\hline Moderate Level & 228 & 70.2 \\
\hline High Level & 88 & 27.1 \\
\hline
\end{tabular}

\subsection{Financial Behavior Pattern}

Table 2 showed the distribution of respondents according to the frequency and percentage of financial behavior characteristics. The findings revealed that less than 40 per cent of the respondents had carefully drawn up their financial budget, reviewed and assessed their expenditures as well as consistently carried out effective financial planning. It was concluded from the responses such as "I do personal financial budget monthly" (29.2\%), "I review and assess expenses at the end of the month" (36.9\%), and "I have plans to reach my financial target" $(37.2 \%)$. Whereas, there were a sizeable number of more respondents who did not draw up their own budget, did not assess their expenses and did not any have a financial plan throughout their lives. 
Table 2. Distribution of respondent's financial behavior

\begin{tabular}{|c|c|c|c|c|c|}
\hline \multirow[t]{2}{*}{ Financial Behavior } & \multicolumn{5}{|c|}{ Frequency (\%) } \\
\hline & 1 & 2 & 3 & 4 & 5 \\
\hline 1. I do a monthly personal budget. & $10(3.1)$ & $39(12.0)$ & $92(28.3)$ & $95(29.2)$ & $89(27.4)$ \\
\hline $\begin{array}{l}\text { 2. I review and assess expenditures every end of the } \\
\text { month. }\end{array}$ & $3(0.9)$ & $30(9.2)$ & $90(27.7)$ & $120(36.9)$ & $82(25.2)$ \\
\hline 3. I plan my budget to achieve my financial objective. & $5(1.5)$ & $19(5.8)$ & $91(28.0)$ & $121(37.2)$ & $89(27.4)$ \\
\hline 4. I pay utility bills on time. & $7(2.2)$ & $6(1.8)$ & $30(9.2)$ & $119(36.6)$ & $163(50.2)$ \\
\hline 5. I pay car loan installment on time. & $12(3.7)$ & $1(0.3)$ & $10(3.1)$ & $85(26.2)$ & $217(66.8)$ \\
\hline 6. I pay house loan installment on time. & $8(2.5)$ & $0(.00)$ & $8(2.5)$ & $73(22.5)$ & $236(72.6)$ \\
\hline 7. I set aside money for saving. & $1(0.3)$ & $6(1.8)$ & $61(18.8)$ & $91(28.0)$ & 166(51.1) \\
\hline 8. I set aside money for emergency. & $5(1.5)$ & $15(4.6)$ & $79(24.3)$ & $103(31.7)$ & $123(37.8)$ \\
\hline 9. I save money specifically for pension. & $40(12.3)$ & $33(10.2)$ & $72(22.2)$ & $86(26.5)$ & $94(28.9)$ \\
\hline 10. I use a credit card when I run out of money. & 191(58.8) & $72(22.2)$ & $49(15.1)$ & $11(3.4)$ & 2(0.6) \\
\hline 11. I withdraw cash from credit card for my expenses. & $270(83.1)$ & $33(10.2)$ & $16(4.9)$ & $4(1.2)$ & 2(0.6) \\
\hline $\begin{array}{l}\text { 12. I have reached the maximum limit on my credit } \\
\text { card usage }\end{array}$ & 273(84.0) & $25(7.7)$ & $17(5.2)$ & $7(2.2)$ & $3(0.9)$ \\
\hline
\end{tabular}

Notes: $1=$ never, $2=$ sometime, $3=$ seldom, $4=$ often, $5=$ always

In references to the responses that answered "I pay utilities bill on time" $(50.2 \%)$, "I pay car installments on time" $(66.8 \%)$ and "I pay his loan on time" $(72.6 \%)$, it could be sum up that many respondents (more than 50\%) had good financial behavior. It showed that most of them consistently paid their monthly bills on time. Probably they were influenced by having a permanent job. However at the same time, there were some of the respondents who stated they "never" paid the monthly bills on time.

The data also showed highest score noted on the Likert scale was for responses such as "I have saved some for monthly saving" (51.1\%), "I set aside some money for emergency fund" (37.8\%) and "I specifically save money for pension" (28.9\%). However, the percentage of responses for positive behavior such a saving consistently for emergency and pension were still relatively low and needed to be improved because it is important to maintain the effective financial behavior in life.

When looked into statements on the usage of credit card such as "I have to use a credit card because running out of cash", "I withdraw cash money from the credit card and spend it", and "I have reached the maximum limit on my credit card usage", many answered "never" with 58.8 per cent, 83.1 per cent, and 84 per cent respectively. Although this trend shows a good sign question remains as to their responses relating to financial matters which are often secretive. However, the issue of lack of cash money should be further investigated as there were some respondents who answered "always" questions indicate above.

\subsection{Dimension of Financial Behavior}

Factor analysis had been carried out and the results showed there were four dimensions on the financial behavior measurement such as planning, cash management, saving and card credit usage (Table 3). Planning dimension referred to statements 1-3 with a mean score of 3.72. Cash management dimension represented by statements 4-6 with a mean score of 4.40 and the saving dimension from statements 7 to 9 had a mean score of 3.85. Lastly, the usage of credit card dimension represented by statements $9-12$ had a mean score of 1.35 . To sum up, it showed that the respondents' financial behavior was the best on the cash management with a mean score of 4.40. In other words, respondents had good behavior in the usage of credit card. However, it still could not guarantee for more effective financial well-being. 
Table 3. Mean of dimension of financial behavior

\begin{tabular}{|c|c|c|}
\hline Dimensions & Mean & Standard Deviation \\
\hline Planning & 3.72 & .866 \\
\hline Cash flow & 4.40 & .798 \\
\hline Saving & 3.85 & .896 \\
\hline Credit & 1.35 & .665 \\
\hline
\end{tabular}

Notes: Mean score calculated based on 5 likert scale items: Higher mean score yields higher financial behavior except for saving dimension.

\subsection{Financial Behavior vs Background Respondents}

\subsubsection{Age}

ANOVA analysis showed in general, the respondents from the age group of more than 45 years old had better financial behavior (Table 4). Specifically in regard to the saving dimension, respondents who were 35-45 years old showed a higher mean score of 4.04, compared with less than 35 years old age (3.71\%) and respondents among the age group of more than 45 years old had a mean score of 3.96. Meanwhile, in term of credit card management dimension, respondents from the age of more than 45 years old had the lowest mean score of 1.19 compared to those with less than 35 years old with a mean score of 1.35 and a mean score of 1.40 for the who were on the 35 to 45 years old age group. The difference in mean scores for all dimensions is significantly correlated with clarifying $(p=0.22 ; p=0.42)$. This trend can be attributed to the older female teacher are the more careful they are on their expenditures.

Table 4. Mean of financial behavior by age

\begin{tabular}{lcccc}
\hline Dimensions & $<35(\mathrm{n}=86)$ & $35-45(\mathrm{n}=144)$ & $>45(\mathrm{n}=95)$ & Sig. \\
\hline Planning & 3.70 & 3.73 & 3.76 & .883 \\
Cash flow & 4.43 & 4.49 & 4.39 & .606 \\
Saving & 3.71 & 3.96 & 4.04 & .022 \\
Credit & 1.35 & 1.40 & 1.19 & .042 \\
\hline
\end{tabular}

\subsubsection{Education Level}

Education levels are an important factor in measuring the financial behavior of the respondents. Their education levels were classified into two categories such as nongraduates and graduates (Table 5). In general, the mean score on the financial behavior of graduates was better than the nongraduates. However, the result of t-test showed there were no significant differences in the mean score of both groups in regards to the four dimensions.

Table 5. Mean of financial behavior by education

\begin{tabular}{lccc}
\hline \multicolumn{1}{c}{ Dimensions } & Non-Graduates $(\mathrm{n}=49)$ & Graduates $(\mathrm{n}=276)$ & Sig. \\
\hline Planning & 3.61 & 3.75 & .270 \\
Cash flow & 4.34 & 4.46 & .317 \\
Saving & 3.83 & 3.93 & .446 \\
Credit & 1.37 & 1.32 & .550 \\
\hline
\end{tabular}

\subsubsection{Monthly Income}

The respondents were also classified into three groups of income such as i) less than RM3500, ii) between RM3500 to RM4500 and iii) more than RM4500 monthly (Table 6). Those respondents who had a monthly income of more than RM4500 showed a higher mean score for saving dimension $(M=4.07)$ as compared to another dimension. Although ANOVA test didn't show differences in the mean scores of all dimensions, in 
general, the respondents with higher monthly income had an effective financial budget.

Table 6. Mean of financial behavior by income

\begin{tabular}{lcccc}
\hline \multicolumn{1}{c}{ Dimensions } & $<$ RM3500 $(\mathrm{n}=136)$ & RM3500-M4500 $(\mathrm{n}=91)$ & $>$ RM4500 $(\mathrm{n}=98)$ & Sig. \\
\hline Planning & 3.70 & 3.82 & 3.69 & .468 \\
Cash flow & 4.44 & 4.41 & 4.48 & .825 \\
Saving & 3.82 & 3.89 & 4.07 & .079 \\
Credit & 1.42 & 1.26 & 1.26 & .079 \\
\hline
\end{tabular}

\subsubsection{Financial Knowledge}

Since prior studies showed the correlation between financial knowledge and financial behavior, it is important to compare both factors (Table 7). In general, there were levels of financial knowledge differences in mean score of financial behaviors for four related dimensions. However, ANOVA result showed that only the different mean score between three levels of financial knowledge in the saving dimension that was significant $(p=0.009)$. This means that respondents with high education background had good financial behavior $(M=4.15)$ with consistent saving practices compared to those respondents with moderate level of education $(M=3.82)$ and low education $(M=3.93)$. Interestingly, the analysis also showed a mean score of good financial behavior in cash management even though at different levels of knowledge (low $=4.26$, moderate $=4.48$, and high $=4.37$ ).

Table 7. Mean of financial behavior by financial knowledge level

\begin{tabular}{lcccc}
\hline \multicolumn{5}{c}{ Financial Knowledge Level } \\
\hline \multicolumn{1}{c}{ Dimensions } & Low $(\mathrm{n}=9)$ & Moderate $(\mathrm{n}=228)$ & High $(\mathrm{n}=88)$ & Sig. \\
Planning & 3.82 & 3.71 & 3.78 & .737 \\
Cash flow & 4.26 & 4.48 & 4.37 & .426 \\
Saving & 3.93 & 3.82 & 4.15 & .009 \\
Credit & 1.70 & 1.34 & 1.26 & .108 \\
\hline
\end{tabular}

\section{Conclusion}

The study analyzed financial behavior among female teachers in term of four different dimensions which are planning, cash management, saving and usage of credit card. The differences in financial behavior in term of age, education level, monthly income and financial background were also analyzed. The rationale of the study was to identify the financial behavior pattern among the female teachers since they were the one who were responsible in teaching and as a role model for the young generation of Malaysia. In addition, financial behavior is important because it influences the level of financial well-being of an individual.

In general, research shows respondents with a relatively good mean score in four related dimensions especially the cash flow dimension regarding payment of utility bills and installment. Findings showed respondents of age more than 45 years old had good financial behavior with good saving practices. Higher income teachers showed good financial behavior with a good mean score in term of saving and usage of credit card. Moreover, teacher respondents with high level of financial education also had good financial behavior in term of saving.

Further study is proposed to identify factors that influence the financial behavior among teachers both male and female teachers in order to come out with effective strategies in improving their financial behavior. It is important to identify the financial behavior because it affects the financial well-being which could also influence work productivity of an individual.

\section{Acknowledgements}

Appreciation to Universiti Kebangsaan Malaysia on research funding UKM-GGPM-CMNB-144-2010, and to the Ministry of Education (MOE) for the cooperation, especially the teachers who participated in this study. 


\section{References}

Baek, E., \& DeVaney, S. A. (2004). Assessing the baby boomers' financial wellness using financial ratios and a subjective measure. Family and Consumer Sciences Research Journal, 421-448.

DeVaney, S. A., Gorham, E. E., Bechman, J. C., \& Haldeman, V. A. (1996). Cash-flow management and credit use: effect of a financial information program. Financial Counseling and Planning, 7, 81-86.

Godwin, D. D. (1994). Antecedents and consequences of newlywed's cash flow management. Financial Counseling and Planning, 5, 161-190.

Godwin, D. D., \& Carroll, D. D. (1986). Financial management attitudes and behavior of husbands and wives. Journal of Consumer Studies and Home Economics, 10, 77-96. http://dx.doi.org/10.1111/j.1470-6431.1986.tb00110.x

Gorham, E. E., DeVaney, S. A., \& Bechman, J. C. (1998). Adoption of financial management practices: a program assessment. Journal of Extension. Retrieved May 25, 2006, from http://www.joe.org/joe/1998april/a5.html

Hilgert, M. A., \& Hogarth, J. M. (2003). Household financial management: the connection between knowledge and behavior. Federal Reserve Bulletin, 8(7), 309-322.

Hira, T. K., \& Mugenda, O. M. (1999). The relationships between self-worth and financial belief, behavior, and satisfaction. Journal of Family and Consumer Sciences, 91(4), 76-82.

Hogarth, J. M., \& Hilgerth, M. A. (2004). Financial knowledge, experience and learning preferences: preliminary results from a new survey of financial literacy. Consumer Interest Annual, 48, 1-7.

Hogarth, J. M., Beverly, S. G., \& Hilgert, M. (2005). Patterns of Financial Behaviors: Implications for Community Educators and Policymakers. Presented at Federal Reserve System Community Affairs Conference. Retrieved March 10, 2005, from http://www.chicagoted.org/cedric/files/2003_conf_paper_session1_hogarth.pdf

Husniyah, A. R., Syuhaily, O., Fazli, M., Amim, O., \& Ahmad, H. H. (2005). Gelagat perancangan kewangan keluarga di Malaysia. Malaysian Journal of Consumer and Family Economics, 8, 27-39.

Joo, S., \& Garman, E. T. (1998). Personal financial wellness may be the missing factor in understanding and reducing worker absenteeism. Personal Finance and Worker Productivity, 2(2), 172-182.

Joo, S., \& Grable, J. E. (2004). An exploratory framework of the determinants of financial satisfaction. Journal of Family and Issues, 25(1), 25-50. http://dx.doi.org/10.1023/B:JEEI.0000016722.37994.9f

Kim, J., \& Garman, E. T. (2004). Financial stress, pay satisfaction and workplace performance. Financial Education, 69-76.

Kim, J., Garman, E. T., \& Sorhaindo, B. (2003). Relationships among credit counseling clients' financial well-being, financial behaviors, Financial Stressor Events, and Health. Financial Counseling and Planning Education, 14(2), 75-87.

Parrotta, J. L., \& Johnson, P. J. (1998). The impact of financial attitudes and knowledge on financial management and satisfaction of recently married individuals. Financial Counseling and Planning, 9(2), 59-74.

Porter, N. M., \& Garman, E. T. (1993). Testing a conceptual model of financial well-being. Financial Counseling and Planning, 4, 135-165.

Rahim, H. A., \& Samad, M. F. A. (2009). The impact of financial management practices on financial well-being of families in Malaysia. Jurnal Pengguna Malaysia, 12, 27-41.

Ramli, Z. (2011). Pengaruh faktor pengetahuan, tingkah laku kewangan dan pembuatan keputusan terhadap kesejahteraan kewangan pekerja sektor awam yang berkahwin, unpublised Thesis Doctor of Philosophy, Universiti Putra Malaysia.

Ramli, Z., Masud, J., Haron, S. A., \& Othman, M. (2010). Pola tingkahlaku kewangan pekerja keluarga dwi-kerjaya. Malaysian Journal of Consumer and Family Economics, 13, 114-124.

Shahnaz, N., Mahdzan, A., \& Abdul Samad, M. F. (2009). Financial management practices of married couples in urban Malaysia. Malaysian Journal of Consumer and Family Economics, 8, 40-50.

Sorhaindo, B., \& Garman, E. T. (2002). Profina Debt Solutions ${ }^{\text {sm }}$ 18-Month Panel Study: Changes in Financial Behavior and Incidence of Financial Stressor. Interim Report. Retrieved December 22, 2004, from http://www.education.incharge.org/_assets/research_reports_and_publications/76.pdf 
Titus, P. M., Fanslow, A. M., \& Hira, T. K. (1989). Networth and financial satisfaction as a function of household money manager's competencies. Home Economics Research Journal, 17(6), $309-317$. http://dx.doi.org/10.1177/1077727X8901700404

Xiao, J. J., Sorhaindo, B., \& Garman, E. T. (2004). Financial behaviors of consumers in credit counseling. Consumer Interest Annual, 50, 131-133.

Xiao, T., \& Shim, S. (2009). Acting for happiness: financial behavior and life satisfaction of college students. Social Indicator Research, 92, 53-68. http://dx.doi.org/10.1007/s11205-008-9288-6 